\title{
Effects of fiber inclusion on growth performance and nutrient digestibility of piglets reared under optimal or poor hygienic conditions $\mathbf{s}^{1,2}$
}

\author{
J. D. Berrocoso, D. Menoyo, P. Guzmán, B. Saldaña, L. Cámara, and G. G. Mateos ${ }^{3}$ \\ Departamento de Producción Animal, Universidad Politécnica de Madrid, 28040 Madrid, Spain
}

\begin{abstract}
Two experiments were conducted to study the effects of inclusion of additional fiber in the Phase I diet on growth performance and nutrient digestibility in piglets reared under "optimal" or "poor" hygienic conditions. In both experiments, the design was completely randomized with a control diet that contained $2.2 \%$ crude fiber and 8 additional isonutritive diets that included 2.5 or $5.0 \%$ of sugar beet pulp (SBP), straw, oat hulls $(\mathrm{OH})$, or wheat middlings (WHM). Preplanned polynomial contrasts were used to study the effects of 1) fiber inclusion (control diet vs. average of the 8 fiber-containing diets), 2) source of fiber, 3) level of fiber, and 4) interaction between source and level of fiber. In Exp. 1 (clean barn), fiber inclusion increased ( $P$ $<0.01)$ the incidence of postweaning diarrhea (PWD) and reduced $(P<0.05)$ feed efficiency and apparent total tract digestibility (ATTD) of all nutrients except that of CP, which was not affected. Piglet performance was not affected by source or level of dietary fiber. The ATTD of all nutrients decreased $(P<0.05)$ as the level of fiber increased and was lower in pigs fed straw or $\mathrm{OH}$ than in pigs fed SBP or WHM. The apparent ileal digestibility of GE and DM decreased $(P<0.05)$ with
\end{abstract}

fiber inclusion, a reduction that was more pronounced $(P<0.05)$ with straw or SBP than with $\mathrm{OH}$ inclusion, with WHM inclusion being intermediate. Fiber inclusion did not affect villous height to crypt depth ratio of the ileum mucosa. The inclusion of $5 \%$ of a fiber source increased Escherichia coli and Lactobacillus counts in the cecum $(P<0.001)$ but the E. coli to Lactobacillus ratio was not affected. In Exp. 2 (dirty barn), fiber inclusion did not affect piglet performance but tended to increase PWD $(P=0.07)$. Also, fiber inclusion reduced $(P<0.05)$ the ATTD of all dietary components except that of CP, which was not affected. Source and level of fiber did not affect ATTD of nutrients except for DM, which was greater for pigs fed SBP than for pigs fed straw $(P<0.05)$. In conclusion, in the current research, pigs reared under optimal hygienic conditions had lower incidence of PWD, better growth performance, and greater DM and GE digestibility than pigs reared under poor hygienic conditions. An excess of dietary fiber was more detrimental for all these traits in piglets reared under optimal hygienic conditions. The effects of the source and level of fiber on piglet performance was limited in the 2 experiments.

Key words: oat hulls, postweaning diarrhea, straw, sugar beet pulp, weaning pigs, wheat middlings

(C) 2015 American Society of Animal Science. All rights reserved.

J. Anim. Sci. 2015.93:3919-3931 doi:10.2527/jas2015-9137

\section{INTRODUCTION}

Dietary fiber (DF) is often related to a reduction of the ADFI and energy digestibility in young pigs (Eggum, 1995; Wellock et al., 2008). Recent research,

\footnotetext{
${ }^{1}$ Funding through Project AGL 2014-56139, Ministerio de Economía y Competitividad, Madrid, 28027 Spain.

${ }^{2}$ The authors thank B. González Zorn and N. Montero Serra for their support on the microbiological analysis.

${ }^{3}$ Corresponding author: gonzalo.gmateos@upm.es

Received March 24, 2015.

Accepted May 30, 2015.
}

however, has shown that the inclusion of moderate amounts of certain fiber sources might reduce the incidence of postweaning diarrhea (PWD) and improve growth performance in weanling pigs (Mateos et al., 2006; Molist et al., 2014). Ingredients that contain appreciable amounts of insoluble fiber, such as oat hulls (OH), straw, and wheat middlings (WHM), might affect the motility and transit time of the digesta throughout the gastrointestinal tract (GIT) and modify piglet performance (Freire et al., 2000; Solà-Oriol et al., 2010). On the other hand, high soluble fiber ingredients, such as sugar beet pulp (SBP), might increase digesta viscosity and decrease rate of feed passage (Molist et 
al., 2014), resulting in an increase in the incidence of PWD (Hermes et al., 2009). Consequently, the physicochemical properties of the fiber sources might affect the environmental conditions within the GIT, which in turn might alter the growth and profile of the gut microflora and pig performance (Bach Knudsen, 1997).

Hygienic conditions of the nursery barn affect health status and growth of young pigs, with healthy animals showing greater ADFI and better growth rate. However, the effects of the inclusion of fiber sources differing in physicochemical characteristics in the diet on growth performance and nutrient digestibility in pigs reared under optimal hygienic conditions (OHC) or poor hygienic conditions (PHC) have not been studied in detail. The hypothesis of this research was that growth performance and nutrient digestibility of the young pigs could be affected in different ways by the inclusion of additional fiber in the diet, depending on the source and level of fiber used as well as on the hygienic conditions of the nursery barn. The study evaluated growth performance and nutrient digestibility of piglets reared in a clean or dirty farm that were fed diets that differed in the source and level of DF.

\section{MATERIALS AND METHODS}

The experimental procedures were approved by the Animal Ethics Committee of the Universidad Politécnica de Madrid and were in compliance with the Spanish guidelines for the care and use of animals in research (Boletín Oficial del Estado, 2007).

\section{Fiber Sources and Experimental Diets}

The straw used (80:20 mixture of wheat and barley straw) was previously treated with $2.0 \%$ sodium hydroxide solution. The SBP was a byproduct of the sugar industry, the $\mathrm{OH}$ resulted from the dehulling of oats used in the manufacturing of infant food formulas, and the WHM was obtained from a wheat flour plant. Straw and SBP were received as $10-\mathrm{mm}$ pellets and $\mathrm{OH}$ and WHM were received as mash. The fiber sources were ground with a hammermill provided with a $2.5-\mathrm{mm}$ screen before being included in their respective experimental diets. The calculated and analyzed composition and the physicochemical properties of the fiber sources are shown in Table 1.

The experimental treatments consisted of a control diet based on corn, soybean meal, and fishmeal that contained $8.0 \%$ lactose and $2.2 \%$ crude fiber and 8 experimental diets that resulted from the combination of 4 sources of fiber (straw, OH, SBP, and WHM) and 2 levels of inclusion (2.5 and 5.0\%). Adjustments in ingredient composition were made to ensure that
Table 1. Calculated and analyzed chemical composition (\%, as-fed basis, unless otherwise indicated) and the physicochemical properties of the fiber sources

\begin{tabular}{|c|c|c|c|c|}
\hline Item & Straw & Oats hulls & $\begin{array}{l}\text { Sugar beet } \\
\text { pulp }\end{array}$ & $\begin{array}{c}\text { Wheat } \\
\text { middlings }\end{array}$ \\
\hline \multicolumn{5}{|l|}{ Calculated composition } \\
\hline $\mathrm{DM}$ & 91.7 & 90.9 & 89.9 & 87.7 \\
\hline $\mathrm{NE}, \mathrm{Mcal} / \mathrm{kg}$ & 1.48 & 0.26 & 0.47 & 1.60 \\
\hline Total ash & 7.2 & 4.9 & 6.6 & 5.0 \\
\hline $\mathrm{CP}$ & 3.7 & 3.8 & 9.2 & 15.1 \\
\hline Starch & 0.7 & 8.7 & - & 19.7 \\
\hline Ether extract & 1.6 & 1.4 & 0.8 & 3.5 \\
\hline Crude fiber & 36.0 & 30.1 & 18.2 & 9.8 \\
\hline NDF & 72.0 & 69.0 & 42.8 & 38.5 \\
\hline $\mathrm{ADF}$ & 46.4 & 36.9 & 22.9 & 12.2 \\
\hline $\mathrm{ADL}$ & 8.4 & 6.2 & 1.7 & 3.4 \\
\hline \multicolumn{5}{|l|}{$\mathrm{SID}^{1} \mathrm{AA}$} \\
\hline Arg & - & 0.10 & 0.17 & 0.82 \\
\hline Ile & - & 0.05 & 0.17 & 0.33 \\
\hline Lys & - & 0.06 & 0.24 & 0.41 \\
\hline Met & - & 0.02 & 0.08 & 0.17 \\
\hline Met + cys & - & 0.03 & 0.11 & 0.38 \\
\hline Thr & - & 0.05 & 0.10 & 0.30 \\
\hline Trp & - & 0.01 & 0.03 & 0.15 \\
\hline Val & & 0.08 & 0.20 & 0.48 \\
\hline \multicolumn{5}{|c|}{ Analyzed composition ${ }^{2}$} \\
\hline $\mathrm{DM}$ & 93.6 & 92.6 & 91.1 & 89.4 \\
\hline GE, Mcal $/ \mathrm{kg}$ & 4.08 & 4.10 & 3.88 & 4.05 \\
\hline Total ash & 7.1 & 4.0 & 5.8 & 4.8 \\
\hline $\mathrm{CP}$ & 2.9 & 3.9 & 9.6 & 14.3 \\
\hline Starch & 1.3 & 9.2 & 1.0 & 18.6 \\
\hline NDF & 74.4 & 71.9 & 40.5 & 38.1 \\
\hline $\mathrm{ADF}$ & 45.9 & 35.4 & 21.3 & 10.9 \\
\hline $\mathrm{ADL}$ & 7.6 & 5.4 & 3.0 & 3.1 \\
\hline Total dietary fiber & 78.5 & 71.3 & 59.0 & 37.2 \\
\hline Insoluble fiber & 74.7 & 70.6 & 47.4 & 32.1 \\
\hline Soluble fiber & 3.8 & 0.7 & 11.6 & 5.1 \\
\hline \multicolumn{5}{|c|}{ Physicochemical properties } \\
\hline $\mathrm{Dgw}^{3} \pm \mathrm{Sgw}^{4}$ & $570 \pm 2.01$ & $610 \pm 1.9$ & $796 \pm 2.1$ & $637 \pm 1.7$ \\
\hline $\mathrm{WHC}^{5} \pm \mathrm{SD}$ & $5.2 \pm 0.411$ & $4.6 \pm 0.75$ & $9.8 \pm 0.21$ & $7.7 \pm 0.38$ \\
\hline $\mathrm{SWC}^{6} \pm \mathrm{SD}$ & $2.4 \pm 0.51$ & $2.4 \pm 0.40$ & $5.3 \pm 0.78$ & $2.1 \pm 0.22$ \\
\hline $\begin{array}{l}{ }^{1} \mathrm{SID}=\text { standardize } \\
{ }^{2} \mathrm{Analyzed} \text { in dupli } \\
{ }^{3} \mathrm{Dgw}=\text { geometric } \\
{ }^{4} \mathrm{SgW}=\text { log normal } \\
{ }^{5} \mathrm{WHC}=\text { water hol } \\
{ }^{6} \mathrm{SWC}=\text { swelling }\end{array}$ & $\begin{array}{l}\text { d ileal digest } \\
\text { icate. } \\
\text { mean diamet } \\
\text { geometric } \mathrm{S} \\
\text { ding capacity } \\
\text { water capacity }\end{array}$ & $\begin{array}{l}\text { tibility. } \\
\text { ter }(\mu \mathrm{m}) \text {. } \\
\text { D. } \\
y(\mathrm{~mL} / \mathrm{g} \mathrm{DM} \\
\text { y }(\mathrm{mL} / \mathrm{g} \mathrm{DM}\end{array}$ & & \\
\hline
\end{tabular}

all diets had similar NE (2.5 Mcal $/ \mathrm{kg})$ and digestible Lys $(1.3 \%)$ content. Other limiting indispensable AA (Ile, Met, Thr, Trp, and Val) and Cys were formulated according to the ideal protein concept as indicated by De Blas et al. (2013). The NDF content, however, varied from $6.4 \%$ in the control diet to $9.3 \%$ in the $5.0 \%$ $\mathrm{OH}$ containing diet. All diets contained $1.0 \%$ of acid- 
washed diatomaceous earth (Celite; Celite Hispánica S.A., Alicante, Spain) as an additional AIA source. No antibiotics or growth promoter additives other than copper sulfate $(160 \mathrm{mg} / \mathrm{kg})$ were included in these diets. The experimental diets that contained $2.5 \%$ of the fiber sources were manufactured by mixing, in equal proportions, the control and the $5.0 \%$ fiber-containing diets. All diets were supplied as $2.5-\mathrm{mm}$ pellets. The ingredient composition and the calculated and analyzed nutrient content of the diets are shown in Table 2.

\section{Experiment 1: Clean Barn}

Pig Husbandry. In total, 216 healthy crossbred pigs (21 $\pm 3 \mathrm{~d}$ of age and $5.8 \pm 0.1 \mathrm{~kg} \mathrm{BW}$ ) from Pietrain $\times$ Large White sires mated to Landrace $\times$ Large White dams were used. The barn was cleaned and kept emptied for $5 \mathrm{mo}$ and then cleaned again and disinfected before the start of the experiment. The average maximum and minimum daily temperature, outside the barn, during the experiment were 21.1 and $8.7^{\circ} \mathrm{C}$, respectively. At arrival to the experimental station, pigs were individually tagged and allotted in groups of 6 to 36 flat-deck pens. All replicate pens had similar average BW and same proportion (50:50) of males and females. Litter origin was not considered for the assignment of pigs to replicates but all pigs belonged to sows from 2 adjacent lactation rooms that were mated the same day. All pens ( 1.70 by $1.25 \mathrm{~m})$ were provided with an individual feeder with 3 spaces and 2 nipple drinkers. Room temperature was maintained at $30 \pm 2^{\circ} \mathrm{C}$ for the first week of the experiment and then reduced $2^{\circ} \mathrm{C}$ per week until reaching $24^{\circ} \mathrm{C}$. The pigs were kept on a $20 \mathrm{~h} / \mathrm{d}$ light program and had free access to feed and water throughout the experiment. Pigs that showed signs of diarrhea, as assessed by veterinarian inspection, were injected with $250 \mathrm{mg}$ enrofloxacine/kg BW (Alsir 5.0\%; Esteve Veterinaria, Barcelona, Spain) for 3 consecutive days.

Experimental Design and Measurements. The experiment was completely randomized with 9 dietary treatments that differed in the ingredient composition of the diet fed from d 0 to 21 postweaning (end of the experiment). Each treatment was replicated 4 times and the experimental unit for all measurements was the pen (6 pigs each). Pigs were individually weighed and feed disappearance was measured by pen at 7,14 , and $21 \mathrm{~d}$ of the experiment. Feed wastage was collected daily from pans placed beneath the feeders and used to correct ADFI. Mortality was recorded as produced. The ADG, actual ADFI, and G:F were calculated from these data by week and cumulatively. The PWD index was estimated by pen as the percentage of days in which pigs had symptoms of diarrhea with respect to total number of days on trial (Mateos et al., 2006).
At the end of the experiment, after growth performance control, representative samples of feces (300 g) were collected by rectal massage from at least 3 pigs from each pen and pooled by replicate. Samples were thawed overnight and homogenized, and representative aliquots $(100 \mathrm{~g})$ were dried at $60^{\circ} \mathrm{C}$ for $48 \mathrm{~h}$ and stored in airtight containers at $+4^{\circ} \mathrm{C}$ until chemical analysis. Apparent total tract digestibility (ATTD) of CP, DM, $\mathrm{OM}$, and GE were determined as indicated by Medel et al. (1999). After the collection of the feces, pigs were fasted for $12 \mathrm{~h}$ and refed under ad libitum conditions for $6 \mathrm{~h}$ to achieve feed intake as high and homogeneous as possible. Then, an intramuscular injection of Imalgene 500 (20 mg ketamine clorhidrate/kg BW; Merial Laboratories S.A., Lyon, France) plus Xilalgesic (2.2 mg Xylazil-20/kg BW; Calier Laboratories S.A., Barcelona, Spain) was administered to 1 pig per pen, chosen at random, to induce general anesthesia. After sedation, pigs were weighed and slaughtered by exsanguination to reduce blood contamination during the sample collection procedure. The GIT was removed from the abdominal cavity and the different segments of the digestive tract were located and tied off to avoid the mixing of the digesta among parts during handling. Individual samples of digesta (approximately $20 \mathrm{~g}$ ) were collected at the terminal ileum (last $2.0 \mathrm{~m}$ of the small intestine), freeze-dried, homogenized using a pestle and a mortar, and stored in airtight containers at $+4^{\circ} \mathrm{C}$ until chemical analyses. The apparent ileal digestibility (AID) of DM, OM, GE, and CP were determined as described by Berrocoso et al. (2014). For the study of the mucosal structure, a $5-\mathrm{cm}$ section of the middle part of the ileum was dissected in all pigs used for the AID study. Villus height, as measured from the tip of the villus to the villus crypt junction, and crypt depth, defined as the depth of the invagination between adjacent villus, were determined. For bacterial count, samples of the cecum content of 4 healthy pigs ( 1 piglet per pen) of 5 of the treatments (control diet and the 4 diets that included $5.0 \%$ extra fiber) were collected in plastic tubes, placed immediately into a portable icebox, and kept in a freezer at $-80^{\circ} \mathrm{C}$ until Lactobacillus and Escherichia coli count. No cecum samples were collected from pigs fed diets with $2.5 \%$ of the fiber sources.

\section{Experiment 2: Dirty Barn}

All husbandry and experimental procedures used were similar to those previously described for Exp. 1. The diets corresponded to the same batches used in the previous experiment, and the pigs $(21 \pm 3 \mathrm{~d}$ of age and $5.85 \pm 0.1 \mathrm{~kg} \mathrm{BW}$ ) were obtained from the same farm and lactation rooms as in Exp. 1. The average maximum and minimum daily temperature, outside 
Table 2. Ingredient composition and calculated and determined analyses ( $\%$, as-fed basis, unless otherwise indicated) of the experimental diets

\begin{tabular}{|c|c|c|c|c|c|c|c|c|c|}
\hline \multirow[b]{2}{*}{ Item } & \multirow[b]{2}{*}{ Control } & \multicolumn{2}{|c|}{ Straw } & \multicolumn{2}{|c|}{ Oat hulls } & \multicolumn{2}{|c|}{ Sugar beet pulp } & \multicolumn{2}{|c|}{ Wheat middlings } \\
\hline & & $2.5 \%$ & $5 \%$ & $2.5 \%$ & $5 \%$ & $2.5 \%$ & $5 \%$ & $2.5 \%$ & $5 \%$ \\
\hline \multicolumn{10}{|l|}{ Ingredient } \\
\hline Corn & 55.2 & 51.3 & 47.5 & 51.4 & 47.5 & 52.2 & 49.2 & 52.4 & 49.6 \\
\hline Soybean meal, $47 \% \mathrm{CP}$ & 15.0 & 15.0 & 15.0 & 15.0 & 15.0 & 15.0 & 15.0 & 15.0 & 15.0 \\
\hline Fermented soybean meal, $54 \% \mathrm{CP}$ & 6.7 & 7.1 & 7.5 & 7.0 & 7.3 & 6.8 & 6.9 & 6.6 & 6.5 \\
\hline Fish meal, $67 \% \mathrm{CP}$ & 6.0 & 6.0 & 6.0 & 6.0 & 6.0 & 6.0 & 6.0 & 6.0 & 6.0 \\
\hline Fiber source & - & 2.5 & 5.0 & 2.5 & 5.0 & 2.5 & 5.0 & 2.5 & 5.0 \\
\hline Dried whey & 11.4 & 11.4 & 11.4 & 11.4 & 11.4 & 11.4 & 11.4 & 11.4 & 11.4 \\
\hline Soy oil & 2.30 & 3.34 & 4.31 & 3.29 & 4.41 & 2.75 & 3.21 & 2.71 & 3.15 \\
\hline Calcium carbonate & 0.21 & 0.19 & 0.17 & 0.20 & 0.19 & 0.17 & 0.13 & 0.21 & 0.20 \\
\hline Monocalcium phosphate & 0.33 & 0.33 & 0.33 & 0.33 & 0.33 & 0.33 & 0.32 & 0.31 & 0.29 \\
\hline Sodium chloride & 0.28 & 0.24 & 0.20 & 0.28 & 0.28 & 0.27 & 0.26 & 0.28 & 0.28 \\
\hline DL-Met, $99 \%$ & 0.19 & 0.20 & 0.20 & 0.20 & 0.20 & 0.19 & 0.19 & 0.19 & 0.19 \\
\hline L-Lys $\mathrm{HCl}, 78 \%$ & 0.33 & 0.33 & 0.32 & 0.33 & 0.32 & 0.32 & 0.32 & 0.33 & 0.32 \\
\hline L-Thr, 99\% & 0.13 & 0.13 & 0.13 & 0.13 & 0.13 & 0.13 & 0.13 & 0.13 & 0.13 \\
\hline L-Trp, $98 \%$ & 0.04 & 0.04 & 0.04 & 0.04 & 0.04 & 0.04 & 0.04 & 0.04 & 0.04 \\
\hline L-Val, $96.5 \%$ & 0.04 & 0.05 & 0.05 & 0.05 & 0.05 & 0.05 & 0.05 & 0.05 & 0.05 \\
\hline Celite $^{1}$ & 1.00 & 1.00 & 1.00 & 1.00 & 1.00 & 1.00 & 1.00 & 1.00 & 1.00 \\
\hline Formic acid, $70.7 \%$ & 0.60 & 0.60 & 0.60 & 0.60 & 0.60 & 0.60 & 0.60 & 0.60 & 0.60 \\
\hline Vitamin and mineral premix ${ }^{2}$ & 0.25 & 0.25 & 0.25 & 0.25 & 0.25 & 0.25 & 0.25 & 0.25 & 0.25 \\
\hline \multicolumn{10}{|l|}{ Calculated composition } \\
\hline $\mathrm{NE}, \mathrm{Mcal} / \mathrm{kg}$ & 2.50 & 2.50 & 2.50 & 2.50 & 2.50 & 2.50 & 2.50 & 2.50 & 2.50 \\
\hline $\mathrm{CP}$ & 20.8 & 20.8 & 20.8 & 20.8 & 20.8 & 20.8 & 20.8 & 20.8 & 20.8 \\
\hline Ether extract & 5.37 & 6.34 & 7.30 & 6.29 & 7.20 & 5.78 & 6.20 & 5.81 & 6.24 \\
\hline $\mathrm{NDF}$ & 6.39 & 7.83 & 9.27 & 7.84 & 9.30 & 7.23 & 8.07 & 7.12 & 7.85 \\
\hline $\mathrm{ADF}$ & 2.93 & 3.92 & 4.90 & 3.76 & 4.58 & 3.41 & 3.90 & 3.14 & 3.35 \\
\hline $\mathrm{ADL}$ & 0.55 & 0.69 & 0.83 & 0.67 & 0.79 & 0.56 & 0.58 & 0.61 & 0.67 \\
\hline \multicolumn{10}{|l|}{$\mathrm{SID}^{3} \mathrm{AA}$} \\
\hline Ile & 0.77 & 0.77 & 0.77 & 0.77 & 0.77 & 0.77 & 0.77 & 0.77 & 0.77 \\
\hline Lys & 1.30 & 1.30 & 1.30 & 1.30 & 1.30 & 1.30 & 1.30 & 1.30 & 1.30 \\
\hline Met & 0.52 & 0.52 & 0.52 & 0.52 & 0.52 & 0.52 & 0.52 & 0.52 & 0.52 \\
\hline Met + Cys & 0.78 & 0.78 & 0.78 & 0.78 & 0.78 & 0.78 & 0.78 & 0.78 & 0.78 \\
\hline Thr & 0.83 & 0.83 & 0.83 & 0.83 & 0.83 & 0.83 & 0.83 & 0.83 & 0.83 \\
\hline $\operatorname{Trp}$ & 0.25 & 0.25 & 0.25 & 0.25 & 0.25 & 0.25 & 0.25 & 0.25 & 0.25 \\
\hline Val & 0.91 & 0.91 & 0.91 & 0.91 & 0.91 & 0.91 & 0.91 & 0.91 & 0.91 \\
\hline $\mathrm{Ca}$ & 0.65 & 0.65 & 0.65 & 0.65 & 0.65 & 0.65 & 0.65 & 0.65 & 0.65 \\
\hline Digestible P & 0.41 & 0.41 & 0.41 & 0.41 & 0.41 & 0.41 & 0.41 & 0.41 & 0.41 \\
\hline \multicolumn{10}{|l|}{ Determined composition ${ }^{4}$} \\
\hline $\mathrm{DM}$ & 90.3 & 90.7 & 90.2 & 90.5 & 90.7 & 90.9 & 90.7 & 90.4 & 90.1 \\
\hline GE, Mcal/kg & 4.13 & 4.15 & 4.13 & 4.13 & 4.16 & 4.13 & 4.10 & 4.11 & 4.13 \\
\hline $\mathrm{CP}$ & 20.6 & 20.1 & 21.3 & 20.2 & 20.1 & 20.5 & 20.6 & 21.0 & 20.9 \\
\hline Total ash & 5.40 & 5.70 & 6.10 & 5.80 & 5.80 & 5.70 & 5.90 & 5.60 & 5.60 \\
\hline NDF & 6.10 & 8.90 & 9.85 & 9.05 & 9.60 & 8.90 & 9.35 & 8.10 & 8.50 \\
\hline $\mathrm{ADF}$ & 2.60 & 4.60 & 5.05 & 4.95 & 5.20 & 4.50 & 4.70 & 3.90 & 4.05 \\
\hline $\mathrm{ADL}$ & 0.40 & 0.87 & 0.95 & 0.75 & 0.88 & 0.65 & 0.70 & 0.58 & 0.75 \\
\hline
\end{tabular}

${ }^{1}$ Acid-washed diatomaceous earth (Celite Hispánica S.A., Alicante, Spain).

${ }^{2}$ Provided the following (per kilogram of diet): 12,000 IU vitamin A (trans-retinyl acetate), 1,900 IU vitamin $\mathrm{D}_{3}$ (cholecalciferol), $30 \mathrm{IU}$ vitamin $\mathrm{E}$ (all-ractocopherol-acetate), $1.8 \mathrm{mg}$ vitamin $\mathrm{B}_{1}$ (thiamine-mononitrate), $5 \mathrm{mg}$ riboflavin, $25 \mathrm{~g}$ niacin, $2.4 \mathrm{mg}$ pyridoxine (pyridoxine $\mathrm{HCl}$ ), $0.03 \mathrm{mg}$ vitamin $\mathrm{B}_{12}$ (cyanocobalamin), $1.8 \mathrm{mg}$ vitamin $\mathrm{K}_{3}$ (bisulfate menadione complex), $15 \mathrm{mg}$ pantothenic acid (d-Ca pantothenate), $0.6 \mathrm{mg}$ folic acid, $0.1 \mathrm{mg} \mathrm{d}-$ biotin, $0.2 \mathrm{mg} \mathrm{Se}\left(\mathrm{Na}_{2} \mathrm{SeO}\right.$ ), $1 \mathrm{mg} \mathrm{I}(\mathrm{KI}), 160 \mathrm{mg} \mathrm{Cu}\left(\mathrm{CuSO}_{4} \cdot \mathbf{5} \mathrm{H}_{2} \mathrm{O}\right), 85 \mathrm{mg} \mathrm{Fe}\left(\mathrm{FeSO}_{4} \cdot \mathbf{7} \mathrm{H}_{2} \mathrm{O}\right), 70 \mathrm{mg} \mathrm{Mn}\left(\mathrm{MnSO}_{4} \cdot \mathbf{H}_{2} \mathrm{O}\right), 120 \mathrm{mg} \mathrm{Zn}(\mathrm{ZnO}), 6 \mathrm{~g}$ and $100 \mathrm{mg} \mathrm{Natuphos} 5000$ (300 FTU/kg; supplied by BASF Española S.A, Tarragona, Spain).

${ }^{3} \mathrm{SID}=$ =standardized ileal digestibility.

${ }^{4}$ According to De Blas et al. (2010). 
the barn, during the experiment were 23.0 and $9.8^{\circ} \mathrm{C}$, respectively. The only difference was that in Exp. 2, pigs were placed in the experimental rearing unit without any cleaning or disinfection. The same truck used to transport the piglets for Exp. 2 was used to remove the pigs from Exp. 1. The variables studied in this experiment were growth performance, PWD, and ATTD of the dietary components, exclusively.

\section{Laboratory Analysis}

Representative samples of the fiber sources, diets, and feces were ground in a laboratory mill (Retsch model Z-I; Retsch GmbH, Stuttgart, Germany), equipped with a 1-mm screen, and analyzed for moisture by oven-drying (method 930.15), total ash by muffle furnace (method 942.05), and nitrogen by Dumas (method 968.06) using a Leco analyzer (model FP-528; Leco Corp., St. Joseph, MI) as indicated by the AOAC International (2000). Gross energy of the samples was determined with an adiabatic bomb calorimeter (model 1356; Parr Instrument Company, Moline, IL) using benzoic acid as the calibration standard. The NDF, ADF, and ADL of the fiber sources and diets were determined as described by Van Soest et al. (1991) and expressed on an ash-free basis. Dietary fiber (method 985.29) and the insoluble fraction (method 991.43) of the fiber sources were analyzed as proposed by the AOAC International (2000). The soluble fraction was calculated by difference between total and insoluble DF. The AIA content of the diets and feces samples of the 2 experiments and of the digesta content of the ileum in Exp. 1 were determined as described by De Coca-Sinova et al. (2011). All the analyses were conducted in duplicate, except for AIA of the diets that were conducted in triplicate.

The geometric mean diameter (Dgw) and geometric SD of the fiber sources were determined in 100g samples using a shaker (Retsch $\mathrm{GmbH}$ ) provided with 8 sieves ranging in mesh from 5,000 to $40 \mu \mathrm{m}$, as described by the American Society of Agricultural Engineers (1995). The water holding capacity (WHC) was measured as indicated by González-Alvarado et al. (2008). Briefly, 2 subsamples (1.0 g DM) of each fiber source were left to soak for $20 \mathrm{~h}$ in an excess of distilled water $(100 \mathrm{~mL})$. Samples were filtered on a fritted glass crucible (porosity 2). The wet sample was weighed after letting the water drain for $10 \mathrm{~min}$, and the WHC, expressed as milliliters per gram DM, was calculated as the amount of water retained. Also, the swelling water capacity (SWC) was determined as indicated by Jiménez-Moreno et al. (2009). Briefly, 2 subsamples $(2.0 \mathrm{~g}$ of $\mathrm{DM})$ of the fiber source were hydrated in $10 \mathrm{~mL}$ of distilled water in a calibrated cylinder $(25 \mathrm{~mL})$ at room temperature. Samples were dispersed by gentle stirring for $5 \mathrm{~min}$ and left undisturbed at room temperature for 22 to $24 \mathrm{~h}$. After equilibration, the bed volume was recorded and expressed as milliliters per gram DM of the original sample.

In Exp. 1, samples of the ileal mucosa were collected and the morphology was evaluated as indicated by Vicente et al. (2009). Briefly, samples were placed into a $10.0 \%$ buffered neutral formaldehyde solution ( $\mathrm{pH} 7.2-7.4)$ and kept on ice for $24 \mathrm{~h}$. After $24 \mathrm{~h}$ immersion in this solution, the samples were carefully cleaned using deionized water. The paraffin sections were stained with hematoxylin and eosin. Morphometric indices for each slide were determined using computer-aided light microscope image analysis. For each segment, the average measurements of 25 villus and crypts, taken from at least 5 different sections, were used. Slides were viewed at $40 \times$ magnification using an Olympus BX-40 light microscope and the image projected by a camera lucid on a digitizer tablet equipped with a mouse cursor (Soft Imagining System; Olympus, GmbH, Hamburg, Germany).

For microbial determination, samples $(5.0 \mathrm{~g})$ of cecum contents were thawed and a 1.0-g subsample was placed in $9.0 \mathrm{~mL}$ buffered peptone water (BioMérieux, Marcy l'Etoile, France) and serially diluted for bacterial analysis. For $E$. coli counts, up to $10^{-3}$ dilutions were inoculated on McConkey agar plates (BioMérieux) and after an incubation period of $22 \mathrm{~h}$ at $37^{\circ} \mathrm{C}$, colonies pink to red in color were counted. For Lactobacillus spp. count, up to 10-6 dilutions were inoculated on MRS (de ManRogosa-Sharpe) agar plates (BD-Difco Laboratories, Sparks, MD) and colonies were counted after $72 \mathrm{~h}$ incubation at $37^{\circ} \mathrm{C}$ under anaerobic conditions.

\section{Statistical Analysis}

Normal distribution of the residuals and variance homogeneity of the data were tested by the UNIVARIATE procedure and the Levene's test, respectively. Data on growth performance and ATTD of nutrients of the 2 experiments and on AID and ileum mucosal morphology in Exp. 1 were analyzed as a completely randomized design using the GLM procedure of SAS (SAS Inst. Inc., Cary, NC). Preplanned polynomial contrasts were performed as indicated by García et al. (2008), taking into account that 8 of the diets formed a $4 \times 2$ factorial. The model studied the effects of 1 ) fiber inclusion in the diet (the control diet vs. average of the 8 fiber-containing diets), 2) source of fiber, 3) level of fiber, and 4) interaction between source and level of fiber. The experimental unit was the pen for all measurements, with 6 pigs per pen for growth performance and ATTD data and 1 pig per pen for AID and ileum mucosal morphology data. In both experiments, data 
Table 3. Influence of fiber inclusion in the diet on growth performance and postweaning diarrhea (PWD) of pigs reared under optimum hygienic conditions from d 0 to 21 on trial (Exp. 1)

\begin{tabular}{|c|c|c|c|c|c|c|c|c|c|c|c|}
\hline \multirow[b]{2}{*}{ Item } & \multirow[b]{2}{*}{ Control } & \multicolumn{4}{|c|}{ Fiber source } & \multicolumn{2}{|c|}{ Fiber level } & \multirow[b]{2}{*}{ SEM $^{1}$} & \multicolumn{3}{|c|}{$P$-value ${ }^{2,3}$} \\
\hline & & Straw & Oat hulls & Sugar beet pulp & Wheat middlings & $2.5 \%$ & $5.0 \%$ & & 1 & 2 & 3 \\
\hline \multicolumn{12}{|l|}{0 to $7 \mathrm{~d}$} \\
\hline ADG, $\mathrm{g}$ & 433 & 377 & 384 & 367 & 409 & 386 & 383 & 26.9 & 0.342 & 0.435 & 0.876 \\
\hline ADFI, $g$ & 421 & 400 & 387 & 368 & 400 & 384 & 393 & 17.4 & 0.108 & 0.186 & 0.436 \\
\hline $\mathrm{G}: \mathrm{F}$ & 1.029 & 0.943 & 0.992 & 0.997 & 1.023 & 1.005 & 0.975 & 0.04 & 0.050 & 0.288 & 0.227 \\
\hline $\mathrm{PWD}^{4}$ & 0.9 & 0.9 & 1.8 & 3.2 & 1.5 & 1.4 & 2.4 & & 0.068 & 0.176 & 0.169 \\
\hline \multicolumn{12}{|l|}{7 to $14 \mathrm{~d}$} \\
\hline ADG, $\mathrm{g}$ & 630 & 560 & 562 & 554 & 602 & 580 & 559 & 44.1 & 0.249 & 0.665 & 0.495 \\
\hline ADFI, $g$ & 785 & 697 & 725 & 718 & 737 & 723 & 716 & 33.1 & 0.127 & 0.686 & 0.760 \\
\hline $\mathrm{G}: \mathrm{F}$ & 0.803 & 0.803 & 0.775 & 0.772 & 0.817 & 0.802 & 0.781 & 0.03 & 0.746 & 0.258 & 0.909 \\
\hline PWD & 0.6 & 1.5 & 2.4 & 2.4 & 1.8 & 1.7 & 2.8 & & 0.044 & 0.779 & 0.248 \\
\hline \multicolumn{12}{|l|}{14 to $21 \mathrm{~d}$} \\
\hline ADG, $\mathrm{g}$ & 655 & 564 & 569 & 587 & 586 & 596 & 557 & 33.6 & 0.059 & 0.871 & 0.126 \\
\hline ADFI, $g$ & 883 & 797 & 758 & 797 & 838 & 830 & 768 & 49.6 & 0.076 & 0.713 & 0.203 \\
\hline $\mathrm{G}: \mathrm{F}$ & 0.742 & 0.708 & 0.751 & 0.737 & 0.699 & 0.718 & 0.725 & 0.03 & 0.336 & 0.385 & 0.462 \\
\hline PWD & 1.8 & 2.7 & 4.4 & 2.9 & 3.0 & 2.3 & 4.5 & & 0.075 & 0.432 & 0.061 \\
\hline \multicolumn{12}{|l|}{0 to $21 \mathrm{~d}$} \\
\hline ADG, $\mathrm{g}$ & 573 & 500 & 505 & 503 & 532 & 523 & 502 & 24.3 & 0.041 & 0.683 & 0.318 \\
\hline ADFI, $\mathrm{g}$ & 696 & 630 & 623 & 628 & 658 & 649 & 629 & 28.0 & 0.035 & 0.764 & 0.327 \\
\hline $\mathrm{G}: \mathrm{F}$ & 0.822 & 0.793 & 0.810 & 0.801 & 0.809 & 0.806 & 0.798 & 0.01 & 0.040 & 0.586 & 0.886 \\
\hline $\mathrm{P} \quad \mathrm{W} \quad \mathrm{D}$ & 1.2 & 1.7 & 2.9 & 2.8 & 2.1 & 1.8 & 3.2 & & 0.006 & 0.208 & 0.009 \\
\hline
\end{tabular}

on PWD showed no normal distribution and, therefore, the CATMOD procedure of SAS was used for statistical analysis. In Exp. 1, cecal bacterial count was evaluated in only 5 of the treatments (the control diet and diets that included $5.0 \%$ of the corresponding fiber source), and the data were analyzed using the GENMOD procedure of SAS, as proposed by Romero et al. (2011). Briefly, a Poisson distribution was used, with the source of fiber as the explanatory variable in the analysis. The experimental unit for this variable was a pig chosen at random per each pen. No interactions between source and level of fiber were detected for any of the variables studied in any of the 2 experiments and, therefore, only main effects are presented. All differences were considered significant at $P<0.05$ and $P$-values between 0.05 and 0.10 were considered a trend.

\section{RESULTS}

The straw, OH, SBP, and WHM contained, by analyses, 74.4, 71.9, 40.5, and 38.1\% NDF and 3.8, $0.7,11.6$, and $5.1 \%$ soluble DF, respectively. The Dgw was $570,610,796$, and $637 \mu \mathrm{m}$, the WHC 5.2, 4.6, 9.8 , and $6.1 \mathrm{~mL} / \mathrm{g} \mathrm{DM}$, and the SWC 4.4, 2.4, 7.3, and $2.1 \mathrm{~mL} / \mathrm{g}$ DM for straw, OH, SBP, and WHM, respectively. The physicochemical characteristics of the fiber sources were similar to those reported by GonzálezAlvarado et al. (2010), Guzmán et al. (2015), and Jaworski et al. (2015). The nutrient content of the diets was close to expected values, confirming that the ingredients were correctly mixed (Table 2 ).

\section{Experiment 1: Clean Barn}

Growth Performance. Mortality was 2.1\% and was not related to treatment (data not shown). Pigs fed the control diet had greater ADG and ADFI $(P<0.05)$ and better G:F and less incidence of PWD $(P<0.05)$ than the average of pigs fed the 8 fiber-containing diets (Table 3). The increase in PWD with additional fiber was significant or tended to be significant for all periods considered. Source and level of fiber did not affect growth performance of the pigs but the incidence of PWD increased as the level of fiber in the diet increased (average of 1.8 and $3.2 \%$ for diets with 2.5 and $5.0 \%$ fiber inclusion, respectively; $P<0.05$ ).

Nutrient Digestibility. On d 21 of the experiment, the ATTD of OM, DM, and GE were greater $(P<0.05)$ for pigs fed the control diet than for the average of pigs fed the fiber-containing diets (Table 4). Source of fiber affected nutrient digestibility, with values of ATTD of OM, $\mathrm{DM}$, and GE being greater $(P<0.05)$ for pigs fed SBP or 
Table 4. Influence of fiber inclusion in the diet on apparent total tract digestibility (ATTD; \%) and apparent ileal digestibility (AID; \%) of nutrients, and ileum mucosa morphology in of pigs reared under optimum hygienic conditions on $\mathrm{d} 21 \mathrm{~d}$ on trial (Exp. 1)

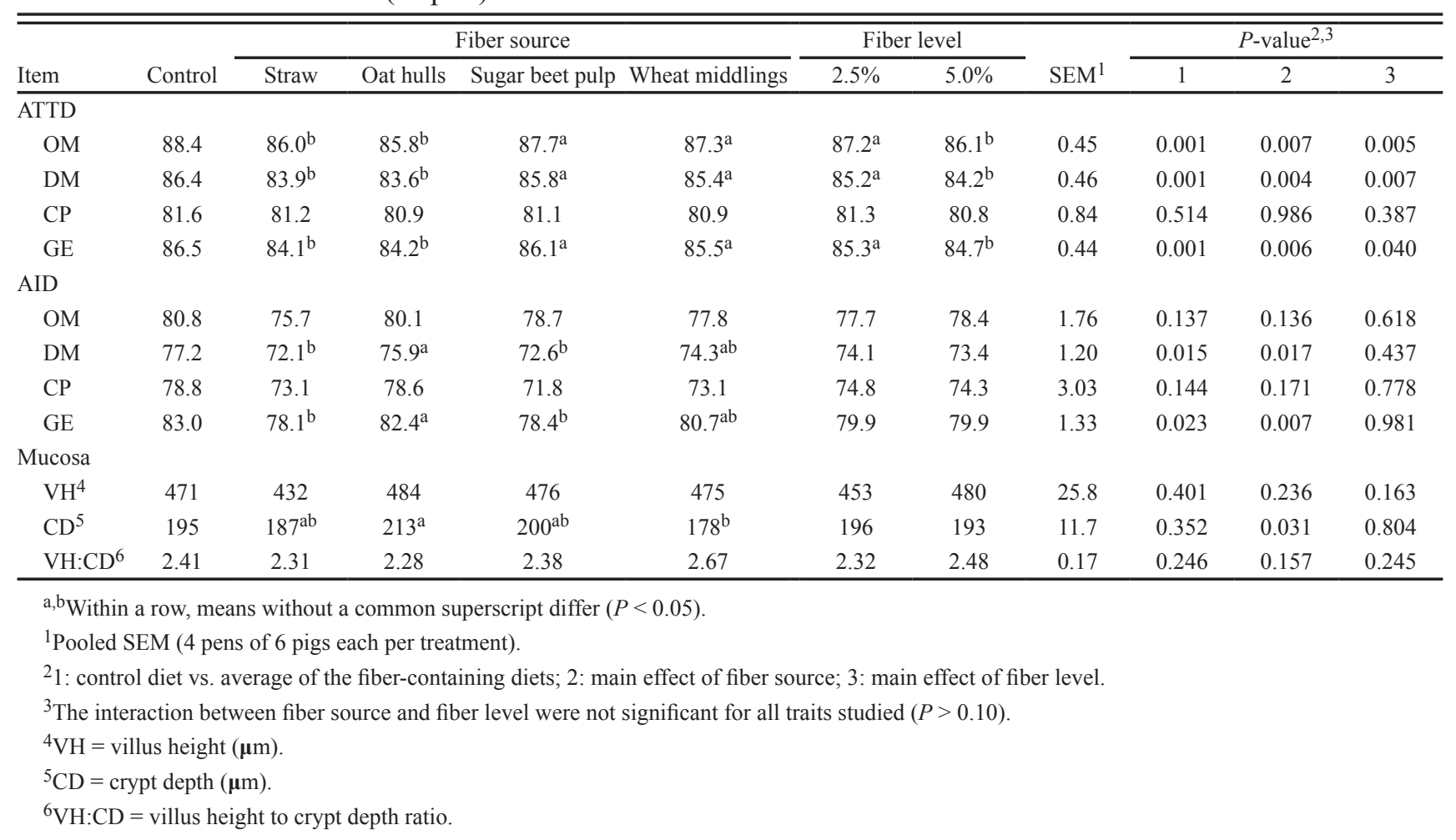

WHM than for pigs fed straw or OH. Also, ATTD of all these nutrients decreased $(P<0.05)$ as the level of fiber in the diet increased. Crude protein digestibility, however, was not affected by source or level of fiber $(P>0.1)$.

The AID of DM and GE were greater $(P<0.05)$ for pigs fed the control diet than for the average of pigs fed the fiber-containing diets (Table 4). Within fiber sources, the AID of DM and GE was greater $(P<0.05)$ for pigs fed $\mathrm{OH}$ than for pigs fed straw or SBP, with pigs fed WHM being intermediate. The AID of CP, however, was not affected by source of fiber. An increase in the level of added fiber from 2.5 to $5.0 \%$ did not affect the AID of any of the nutrients studied $(P>0.1)$.

Ileum Mucosa Morphology and Cecum Microbiota. Mucosa morphology was similar for pigs fed the control diet than for the average of pigs fed the fiber-containing diets (Table 4). Source of fiber, however, affected crypt depth, which was greater in pigs fed $\mathrm{OH}$ than in pigs fed WHM, with pigs fed straw or SBP being intermediate $(P<0.05)$. Villus height and villus height to crypt depth ratio were not affected by source of fiber. An increase in the level of fiber of the diet did not affect any of the mucosal morphology traits studied. Regarding cecum microbiota, Lactobacillus $(P<0.05)$ and $E$. coli $(P<$ 0.05 ) counts were lower in pigs fed the control diet than in pigs fed the $5.0 \%$ fiber-containing diets (Table 5). Within fiber sources, Lactobacillus count was greater for pigs fed $\mathrm{OH}$ than for pigs fed straw, with pigs fed SBP and WHM being intermediate $(P<0.05)$. Also, $E$ coli count was lower in pigs fed SBP than in pigs fed WHM, with pigs fed straw or $\mathrm{OH}$ being intermediate $(P<0.05)$. Neither source nor level of fiber affected the Lactobacillus to E. coli ratio $(P>0.1)$.

Table 5. Influence of inclusion of $5 \%$ of a fiber in the diet on cecum bacterial count (log cfu/g wet digesta) in pigs reared under optimum hygienic conditions on $\mathrm{d} 21 \mathrm{~d}$ on trial (Exp. 1)

\begin{tabular}{lccccccc}
\hline & & \multicolumn{9}{c}{ Fiber source } & \multicolumn{2}{c}{$P$-value ${ }^{1}$} \\
\cline { 3 - 6 } Item & Control & Straw & Oat hulls & Sugar beet pulp & Wheat middlings & 1 & 2 \\
\hline Lactobacillus & 14.4 & $14.7^{\mathrm{d}}$ & $15.6^{\mathrm{a}}$ & $15.1^{\mathrm{b}}$ & $14.9^{\mathrm{c}}$ & $<0.001$ & $<0.001$ \\
Escherichia coli & 7.7 & $10.6^{\mathrm{c}}$ & $10.7^{\mathrm{b}}$ & $7.8^{\mathrm{d}}$ & $12.0^{\mathrm{a}}$ & $<0.001$ & $<0.001$ \\
Lactobacillus: Escherichia coli $^{2}$ & 1.9 & 1.8 & 1.7 & 2.0 & 1.4 & 0.728 & 0.852 \\
\hline
\end{tabular}

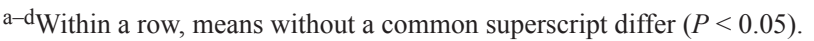

${ }_{1}^{1}$ : control diet vs. average of the 4 fiber-containing diets; 2 : main effect of fiber source.

${ }^{2}$ Ratio between Lactobacillus and E. coli counts expressed as ratio of cfu. 
Table 6. Influence of fiber inclusion in the diet on growth performance and postweaning diarrhea (PWD) of piglets reared under poor hygienic conditions from 0 to $21 \mathrm{~d}$ on trial (Exp. 2)

\begin{tabular}{|c|c|c|c|c|c|c|c|c|c|c|c|}
\hline \multirow[b]{2}{*}{ Item } & \multirow[b]{2}{*}{ Control } & \multicolumn{4}{|c|}{ Fiber source } & \multicolumn{2}{|c|}{ Fiber level } & \multirow[b]{2}{*}{ SEM $^{1}$} & \multicolumn{3}{|c|}{$P$-value ${ }^{2,3}$} \\
\hline & & Straw & Oat hulls & Sugar beet pulp & Wheat middlings & $2.5 \%$ & $5.0 \%$ & & 1 & 2 & 3 \\
\hline \multicolumn{12}{|l|}{0 to $7 \mathrm{~d}$} \\
\hline ADG, $g$ & 373 & 355 & 378 & 375 & 387 & 382 & 365 & 18.4 & 0.326 & 0.171 & 0.500 \\
\hline ADFI, $g$ & 395 & 375 & 396 & 402 & 408 & 402 & 388 & 15.2 & 0.211 & 0.203 & 0.178 \\
\hline $\mathrm{G}: \mathrm{F}$ & 0.944 & 0.947 & 0.955 & 0.933 & 0.949 & 0.950 & 0.941 & 0.03 & 0.982 & 0.855 & 0.787 \\
\hline $\mathrm{PWD}^{4}$ & 2.4 & 4.2 & 4.6 & 3.0 & 3.6 & 4.7 & 3.0 & & 0.266 & 0.707 & 0.156 \\
\hline \multicolumn{12}{|l|}{7 to $14 \mathrm{~d}$} \\
\hline ADG, $g$ & 411 & 384 & 383 & 401 & 380 & 388 & 386 & 34.6 & 0.681 & 0.939 & 0.438 \\
\hline ADFI, $g$ & 556 & 499 & 515 & 530 & 516 & 517 & 513 & 34.8 & 0.885 & 0.861 & 0.266 \\
\hline G:F & 0.739 & 0.770 & 0.744 & 0.757 & 0.736 & 0.750 & 0.752 & 0.03 & 0.525 & 0.722 & 0.814 \\
\hline PWD & 5.4 & 5.4 & 7.0 & 5.6 & 3.3 & 5.7 & 5.7 & & 0.976 & 0.134 & 0.502 \\
\hline \multicolumn{12}{|l|}{14 to $21 \mathrm{~d}$} \\
\hline ADG, $g$ & 420 & 412 & 466 & 444 & 476 & 447 & 452 & 34.8 & 0.541 & 0.287 & 0.707 \\
\hline ADFI, $g$ & 558 & 573 & 633 & 611 & 631 & 614 & 610 & 34.6 & 0.695 & 0.337 & 0.355 \\
\hline $\mathrm{G}: \mathrm{F}$ & 0.753 & 0.719 & 0.736 & 0.727 & 0.754 & 0.728 & 0.741 & 0.02 & 0.487 & 0.463 & 0.403 \\
\hline PWD & 6.5 & 11.5 & 11.4 & 8.9 & 10.7 & 11.1 & 10.6 & & 0.060 & 0.641 & 0.581 \\
\hline \multicolumn{12}{|l|}{0 to $21 \mathrm{~d}$} \\
\hline ADG, g & 401 & 384 & 409 & 407 & 414 & 406 & 401 & 21.8 & 0.697 & 0.531 & 0.329 \\
\hline ADFI, $g$ & 503 & 482 & 515 & 514 & 518 & 511 & 514 & 21.8 & 0.667 & 0.379 & 0.187 \\
\hline $\mathrm{G}: \mathrm{F}$ & 0.798 & 0.795 & 0.795 & 0.791 & 0.799 & 0.794 & 0.796 & 0.01 & 0.787 & 0.938 & 0.546 \\
\hline PWD & 4.8 & 7.0 & 7.7 & 5.8 & 5.8 & 7.2 & 6.5 & & 0.070 & 0.305 & 0.135 \\
\hline
\end{tabular}

${ }^{1}$ Pooled SEM (4 pens of 6 pigs each per treatment).

${ }^{2}$ 1: control diet vs. average of the fiber-containing diets; 2 : main effect of fiber source; 3 : main effect of fiber level.

${ }^{3}$ The interaction between fiber source and fiber level were not significant for all traits studied $(P>0.10)$.

${ }^{4}$ Expressed as percentage of days in which piglets had symptoms of diarrhea with respect to total number of days on trial (Mateos et al., 2006).

\section{Experiment 2: Dirty Barn}

Growth Performance. Mortality was 3.2\% and was not related to treatment (data not shown). From d 0 to 21 of the experiment, growth performance was similar for pigs fed the control diet than for the average of pigs fed the fiber-containing diets. However, PWD tended to be greater $(P=0.07)$ when additional fiber was included in the diet (Table 6). Neither source nor level of fiber affected growth performance or PWD of the pigs $(P>0.1)$.

Total Tract Apparent Digestibility. The ATTD of OM $(P<0.1)$, DM $(P<0.05)$, and GE $(P<0.05)$ were greater for pigs fed the control diet than for the average of pigs fed the fiber-containing diets, but CP digestibility was not affected (Table 7). Source of fiber did not affect the digestibility of the dietary components $(P>$ 0.1 , except for DM, which was greater for pigs fed SBP than for pigs fed straw, with pigs fed WHM or OH being intermediate $(P<0.05)$. Level of fiber did not affect the ATTD of any of the nutrients studied.

\section{DISCUSSION}

\section{Influence of Dietary Fiber Level}

Growth Performance and Postweaning Diarrhea. In most studies (Anguita et al., 2007; Wellock et al., 2008), additional fiber reduced ADFI and growth performance in young pigs kept under OHC. Bikker et al. (2006) reported that the inclusion of a mixture of $8.4 \%$ WHM and $4.0 \%$ SBP in the diet reduced ADG by $14.3 \%$ and feed efficiency by $6.0 \%$ in pigs for the first $28 \mathrm{~d}$ postweaning. In contrast, Gerritsen et al. (2012) did not find any adverse effect on growth performance for the first $7 \mathrm{~d}$ postweaning when $15.0 \%$ of a combination of insoluble fiber sources $(\mathrm{OH}$ and straw) was included in a standard cereal-soybean meal diet. In the current research, pigs reared under $\mathrm{OHC}$ had, on average, 10.9 and $8.8 \%$ lower ADG and ADFI and $2.3 \%$ worse G:F when fed the fiber-containing diets than when fed the control diet but no significant effects were detected under PHC $(0.6,0.8$, and $0.1 \%$ for ADG, ADFI, and G:F, respectively). Also, PWD increased with increases in fiber content of the diet, with effects being more pronounced in pigs reared under $\mathrm{OHC}$ (2.4 vs. $1.2 \%$, for the control pigs) than for pigs reared under PHC ( 6.5 vs. $4.8 \%$ for the control pigs). The data indicate that young 
Table 7. Influence of fiber inclusion in the diet on the apparent total tract digestibility of nutrients on $\mathrm{d} 21$ on trial (Exp. 2)

\begin{tabular}{|c|c|c|c|c|c|c|c|c|c|c|c|}
\hline \multirow[b]{2}{*}{ Item } & \multirow[b]{2}{*}{ Control } & \multicolumn{4}{|c|}{ Fiber source } & \multicolumn{2}{|c|}{ Fiber level } & \multirow[b]{2}{*}{ SEM $^{1}$} & \multicolumn{3}{|c|}{$P$-value ${ }^{2,3}$} \\
\hline & & Straw & Oat hulls & Sugar beet pulp & Wheat middlings & $2.5 \%$ & $5.0 \%$ & & 1 & 2 & 3 \\
\hline$\overline{\mathrm{OM}}$ & 88.3 & 85.3 & 85.3 & 86.8 & 86.1 & 86.4 & 85.4 & 0.71 & 0.086 & 0.166 & 0.705 \\
\hline DM & 86.6 & $82.9^{\mathrm{b}}$ & $83.3^{\mathrm{ab}}$ & $84.7^{\mathrm{a}}$ & $83.8^{\mathrm{ab}}$ & 84.0 & 83.3 & 0.60 & 0.047 & 0.048 & 0.144 \\
\hline $\mathrm{CP}$ & 83.3 & 80.2 & 80.5 & 78.9 & 79.8 & 80.4 & 79.2 & 0.94 & 0.160 & 0.379 & 0.103 \\
\hline GE & 86.8 & 83.3 & 83.6 & 84.7 & 84.1 & 84.1 & 83.7 & 0.60 & 0.045 & 0.161 & 0.252 \\
\hline
\end{tabular}

a,bWithin a row, means without a common superscript differ $(P<0.05)$.

${ }^{1}$ Pooled SEM (4 pens of 6 pigs each per treatment).

21: control diet vs. average of the fiber-containing diets; 2 : main effect of fiber source; 3 : main effect of fiber level.

${ }^{3}$ The interaction between fiber source and fiber level were not significant for all traits studied $(P>0.10)$.

pigs respond in different ways to fiber inclusion, depending on the hygienic status of the barn. We hypothesize that the inclusion of moderate amounts of fiber in Phase I diets of pigs kept under PHC might reduce ADFI and improve ileal mucosa function, helping the young animal to cope with the negative effects caused by a greater concentration of potential pathogens in the environment. Under $\mathrm{OHC}$, however, an extra defense against the adherence of pathogens to the mucosa wall might not be needed, and the extra fiber might produce a greater reduction in ADFI and an increase in PWD, penalizing piglet performance.

Most of the experiments showing a negative effect of fiber inclusion on PWD and growth performance of piglets have been conducted using either a high-fiber control diet or experimental diets that included high levels of extra fiber (Pluske et al., 1998; Pascoal et al., 2012). In this respect, Mateos et al. (2006) reported that the inclusion of up to $4.0 \% \mathrm{OH}$ into a low-fiber diet (5.5\% NDF and 2.2\% crude fiber) reduced PWD in weaning pigs from 21 to $41 \mathrm{~d}$ after weaning. The authors detected an interaction between type of cereal and inclusion of $\mathrm{OH}$ in the diet; the inclusion of $\mathrm{OH}$ reduced PWD and improved growth performance in weanling pigs fed rice but had no effect in pigs fed an isonutritive diet based on corn. The NDF was lower ( 3.4 vs. $6.5 \%)$ in the rice diet than in the corn diet, and the inclusion of $4.0 \% \mathrm{OH}$ increased NDF to 6.5 and $9.0 \%$, respectively. The data suggest that additional fiber might be less beneficial in piglets fed high-NDF diets than in piglets fed low-NDF diets.

Source of fiber did not affect PWD or growth performance of the pigs in either of the 2 experiments. In contrast, Hedemann et al. (2006) reported that pigs fed a diet that included $9.6 \%$ barley hulls had better ADG, ADFI, and G:F for the first $7 \mathrm{~d}$ postweaning than pigs fed a diet that included $7.0 \%$ pectin. Soluble fiber sources, such as pectin and SBP, have a high WHC and SWC, which increases viscosity, bulk of the digest, and water retention (Jørgensen et al., 2007; González -Alvarado et al., 2008). As a result, soluble fibers cause physical dis- tension of the walls of the GIT, affect the physiological mechanisms that regulate satiety and ADFI, and might increase the occurrence of PWD (Molist et al., 2014). However, once the pigs adapt to solid feed consumption ( 7 to $10 \mathrm{~d}$ postweaning), moderate amounts of soluble fiber promote healthy fermentation of the undigested nutrients. Soluble fiber sources are easily fermented by the GIT microflora and help to create a stable environment within the GIT, resulting in a reduction of PWD. Lizardo et al. (1997) reported improved digestive functions from 33 to $39 \mathrm{~d}$ of age in piglets weaned at 25 $\mathrm{d}$ of age and fed a diet with $12.0 \% \mathrm{SBP}$ as compared with piglets fed a control diet. In the current experiment, however, pigs fed the SBP-containing diet had ADFI similar to pigs fed the insoluble fiber-containing diet and, therefore, no differences in ADG or feed efficiency should be expected. All this information corroborates the suggestion of Lindberg (2014) and Molist et al. (2014), indicating that factors others than fiber content of the diet, such as characteristic of the diet and age, management, and rearing conditions of the experimental pigs, might modify the response of young pigs to fiber inclusion in the diet.

Nutrient Digestibility. In both experiments, the digestibility of all nutrients, except for $\mathrm{CP}$, which was not affected, decreased with the inclusion of fiber in the diet, in agreement with most published reports (Hogberg and Lindberg, 2006; Molist et al., 2010; Zhang et al., 2013). Mateos et al. (2007) reported also that the inclusion of $2.0 \% \mathrm{OH}$ in a control diet that contained $6.5 \%$ NDF reduced OM digestibility from 87.0 to $85.0 \%$ but that CP digestibility was not affected. However, because of the limited number of replicates used, the possibility of existing differences among treatments passing undetected cannot be ruled out.

Source of fiber affected nutrient digestibility in different ways. In Exp. 1, the ATTD of OM, DM, and GE was greater in pigs fed SBP or WHM than in pigs fed straw or OH. In Exp. 2, conducted under PHC, DM digestibility was also greater in pigs fed SBP than in pigs fed straw, with pigs fed $\mathrm{OH}$ or WHM being intermedi- 
ate. Freire et al. (2000) reported greater DM digestibility when $20.0 \%$ SBP was included in a corn-fishmeal diet at the expense of the same amount of WHM. Also, Chabeauti et al. (1991) reported greater ATTD of GE in growing pigs when fed $16 \%$ SBP or $21.0 \%$ WHM than when fed 22.0\% straw. Moreover, Molist et al. (2009) observed similar OM digestibility in pigs fed diets with $6.0 \%$ SBP or $8.0 \%$ WHM. The greater ATTD of DM and GE with SBP or WHM than with more lignified fiber sources, such as straw or $\mathrm{OH}$, was expected because of the negative effects of lignin on fiber fermentation in the large intestine of the pigs (Longland et al., 1994). Sugar beet pulp has a high pectin content, a feed fraction that is easily fermented at the terminal ileum and the colon (Drochner et al., 2004). Wheat middlings has a high fiber content but also is rich in starch. In addition, the fibrous fraction of WHM is relatively low in insoluble fiber (De Blas et al., 2010). Consequently, SBP and WHM should have greater nutrient digestibility than more lignified, less soluble fiber sources, such as straw or $\mathrm{OH}$ (Chabeauti et al., 1991; González-Alvarado et al., 2010).

In Exp. 1, the AID of DM and GE was greater in pigs fed $\mathrm{OH}$ than in pigs fed straw or SBP, with pigs fed WHM being intermediate. In Exp. 2, the AID of nutrients was not measured, but the highest ATTD values corresponded to pigs fed the SBP containing diet. Lizardo et al. (1997) reported similar ATTD but lower AID of GE in 25-d-old piglets fed a control diet than in pigs fed a diet supplemented with $12.0 \% \mathrm{SBP}$, consistent with the results reported herein. Viscous fiber sources such as SBP penalize the mixing of enzymes and digesta contents and facilitate the formation of an unstirred water layer in the intestinal surface, thereby creating a physical barrier to nutrient absorption (Graham and Aman, 1991). Probably, the gelling properties of the pectin present in the SBP were responsible for the negative effects on AID of GE and DM observed. It should be taken into account that in all cases, the proportion of fiber particles in the feces should increase with the inclusion of insoluble, highly lignified fiber sources, because they are not fermented at any high extent in the large intestine. Consequently, the ATTD of the NDF will be greater in diets containing $\mathrm{SBP}$ than in diets containing $\mathrm{OH}$ or other insoluble fiber sources, such as $\mathrm{OH}$ or straw.

\section{Ileum Mucosa Morphology and Cecum} Microbiota. Villous height to crypt depth ratio is a useful criterion for estimating the digestive capacity of the small intestine (Montagne et al., 2003). In Exp. 1, villus height and villus height to crypt depth ratio were not affected by fiber inclusion but crypt depth was greater in pigs fed $\mathrm{OH}$ than in pigs fed WHM, with pigs fed straw or SBP being intermediate. Hedemann et al. (2006) indicated that an increase in crypt depth not accompanied by changes in villous height had a minimal impact on the overall digestive capacity minimal in healthy pigs.

In the current research, an increase in fiber content of the diet increased Lactobacillus and E. coli counts in the cecum with differences being significant in most cases. However, the Lactobacillus to E. coli ratio was not affected. Thomson et al. (2012) also reported an increase in Lactobacillus count in pigs fed a diet that contained $6.0 \% \mathrm{SBP}$ as compared with pigs fed the control diet. An increase in Lactobacillus favors the production of lactic acid and reduces ceca $\mathrm{pH}$, which may allow the piglets to sooner achieve a stable microbiota with predominance of commensal bacteria such as Lactobacillus (Ravindran and Kornegay, 1993). In the current experiment, SBP inclusion decreased E. coli count in the cecum as compared with the inclusion of the other fiber sources, probably because of an increase in fermentation rate in the large intestine with greater production of VFA as reported by Konstantinov et al. (2003) and Schiavon et al. (2004).

\section{Hygienic Conditions of the Barn}

Poor hygienic conditions reduce growth performance of the pigs (Le Floc'h et al., 2009; Montagne et al., 2012). In the current research, the most noticeable differences observed between both groups of pigs were the greater ADFI and lower PWD in pigs reared under $\mathrm{OHC}$, which resulted in pronounced improvements in ADG without any major effect on feed efficiency. Goodband et al. (2014) suggested that an increase in the pathogen load in the environment stimulates proinflammatory cytokine production and endocrine shifts, resulting in a decrease in ADFI. In this respect, Le Floc'h et al. (2009) suggested that the reduced growth rate observed in pigs kept under PHC was associated with a greater inflammatory response. In addition, PHC increase bacterial density in the barn and reduce microflora diversity in the GIT, reducing health status and growth performance of the piglets (Montagne et al., 2012). The lack of negative effects of the PHC on feed efficiency, in spite of the reduced ADFI observed, is not easy to explain. In the current research, piglets showing any symptom of digestive processes were immediately treated with antibiotics and kept under severe veterinary scrutiny. Therefore, fewer effects of poor health status of the pigs on feed efficiency should be expected in the current experiment than under practical commercial conditions.

Fiber inclusion reduced ADG by $10.9 \%$ and ADFI by $8.8 \%$ and improved $\mathrm{G}: \mathrm{F}$ by $2.3 \%$, on average, in pigs reared under $\mathrm{OHC}$ but did not have any significant effect in pigs reared under PHC. Montagne et al. (2012) compared the growth of piglets reared under $\mathrm{OHC}$ and $\mathrm{PHC}$ and fed either a control diet or an experimental 
diet that included a mixture of $6.0 \%$ SBP and $2.0 \%$ soy hulls. Pigs reared under PHC had 6\% greater ADG when fed the low-fiber diet than when fed the high-fiber diet. However, no differences were detected in pigs reared $\mathrm{OHC}$, the opposite to the result reported herein. The reasons for the discrepancies between the 2 researches are not know. In the research of Montagne et al. (2012), the ADFI for the first $14 \mathrm{~d}$ postweaning was $12.0 \%$ lower in pigs fed the high-fiber diet than in pigs fed the low-fiber diet, whereas in the current research, the difference was of only $7.5 \%$. In addition, in the research of Montagne et al. (2012), the control and experimental diets contained 10.9 and $11.2 \% \mathrm{NDF}$, respectively, whereas in the current research, the NDF content was $6.1 \%$ for the control diet and within the range of 7.5 to $8.6 \%$ NDF for the fiber-containing diets. In this respect, Mateos et al. (2012) and Jiménez-Moreno et al. (2013) have reported, in broilers, a beneficial effect of the inclusion of moderate amounts of fiber to low-fiber diets but that the excess was detrimental for broiler growth.

In the current research, the inclusion of fiber increased PWD of the pigs in both experiments but the increase was more pronounced under $\mathrm{OHC}$ than under PHC. Montagne et al. (2012) reported also an increase in PWD with increases in DF in weanling pigs reared under PHC but not under OHC. These data suggest that the inclusion of moderate amounts of fiber sources (less than $5.0 \%)$ to a control diets with a low fiber content $(6.0 \%$ $\mathrm{NDF}$ ) might be less detrimental in pigs reared in farms under $\mathrm{PHC}$ than in pigs reared in farms under $\mathrm{OHC}$

In summary, the inclusion of additional fiber in the diet increased PWD and reduced nutrient digestibility and feed efficiency in piglets reared under OHC. However, when the pigs were reared under PHC, no negative effects of supplemental fiber on growth performance were detected, although PWD was still greater and nutrient digestibility lower with the high-fiber diets. Source of fiber did not affect growth performance in any of the 2 experiments, but the inclusion of SBP and WHM improved ATTD of all nutrients except CP. Also, the inclusion of $\mathrm{OH}$ improved the AID of GE as compared with the inclusion of straw or SBP. The inclusion of $5.0 \%$ of a fiber source increased, in most cases, Lactobacillus and E. coli counts in the cecum. Consequently, the more appropriate source and level of fiber in commercial diets for weaning pigs might depend on the hygienic status of the farm.

\section{LITERATURE CITED}

American Society of Agricultural Engineers. 1995. Method of determining and expressing fineness of feed materials by sieving. In: Agriculture engineers yearbook of standards. ASAE Standard S319.2. Am. Soc. Agric. Eng., St. Joseph, MO. p. 461-462.
Anguita, M., J. Gasa, M. Nofrarias, S. M. Martín-Orúe, and J. F. Pérez. 2007. Effect of coarse ground corn, sugar beet pulp and wheat bran on the voluntary intake and physicochemical characteristics of digesta of growing pigs. Livest. Sci. 107:182-191. doi:10.1016/j.livsci.2006.09.016.

AOAC International. 2000. Official methods of analysis, 17th ed. AOAC Int., Gaithersburg, VA.

Bach Knudsen, K. E. 1997. Carbohydrates and lignin contents of plant materials used in animal feeding. Anim. Feed Sci. Technol. 67:319-338. doi:10.1016/S0377-8401(97)00009-6.

Berrocoso, J. D., L. Cámara, P. G. Rebollar, P. Guzmán, and G. G. Mateos. 2014. Influence of source and micronization (fine grinding) of soybean meal on growth performance, nutrient digestibility and ileal mucosa morphology of Iberian piglets. Animal 8:555-564. doi:10.1017/S1751731113002449.

Bikker, P., A. Dirkzwager, J. Fledderus, P. Trevisi, I. le HuërouLuron, J. P. Lallès, and A. Awati. 2006. The effect of dietary protein and fermentable carbohydrates levels on growth performance and intestinal characteristics in newly weaned piglets. J. Anim. Sci. 84:3337-3345. doi:10.2527/jas.2006-076.

Boletín Oficial del Estado (BOE). 2007. Ley 32/2007 de 7 de Noviembre para el cuidado de los animales, en su explotación, transporte, experimentación y sacrificio (In Spanish). Bol. Of. Estado 268:45914-45920.

Chabeauti, E., J. Noblet, and B. Carré. 1991. Digestion of plant cell walls from four different sources in growing pigs. Anim. Feed Sci. Technol. 32:207-213. doi:10.1016/03778401(91)90024-M.

De Blas, C., J. Gasa, and G. G. Mateos, editors. 2010. Fundación española desarrollo nutrición animal. Normas FEDNA para la Formulación de Piensos Compuestos. Fund. Esp. Desarro. Nutr. Anim. 3rd ed. (In Spanish.) Fundación Española Desarrollo Nutrición Animal, Madrid, Spain.

De Blas, C., J. Gasa, and G. G. Mateos, editors. 2013. Necesidades nutricionales para ganado porcino. 2nd rev. (In Spanish.) Fundación Española Desarrollo Nutrición Animal, Madrid, Spain.

De Coca-Sinova, A., G. G. Mateos, J. M. González-Alvarado, C. Centeno, R. Lázaro, and E. Jiménez-Moreno. 2011. Comparative study of two analytical procedures for the determination of acid insoluble ash for evaluation of nutrient retention in broiler diets. Span. J. Agric. Res. 9:761-768. doi:10.5424/sjar/20110903-439-10.

Drochner, W., A. Kerler, and B. Zacharias. 2004. Pectin in pig nutrition, a comparative review. J. Anim. Physiol. Anim. Nutr. 88:367-380. doi:10.1111/j.1439-0396.2004.00490.x.

Eggum, B. O. 1995. The influence of dietary fibre on protein digestion and utilization in monogastrics. Arch. Anim. Nutr. 48:89-95.

Freire, J. P. B., A. J. G. Guerreiro, L. F. Cunha, and A. Aumaitre. 2000. Effect of dietary fibre source on total tract digestibility, caecum volatile fatty acids and digestive transit time in the weaned piglet. Anim. Feed Sci. Technol. 87:71-83. doi:10.1016/S0377-8401(00)00183-8.

García, M., R. Lázaro, M. A. Latorre, M. I. Gracia, and G. G. Mateos. 2008. Influence of enzyme supplementation and heat processing of barley on digestive traits and productive performance of broilers. Poult. Sci. 87:940-948. doi:10.3382/ps.2007-00266.

Gerritsen, R., P. van der Aar, and F. Molist. 2012. Insoluble nonstarch polysaccharides in diets for weaned piglets. J. Anim. Sci. 90:318-320. doi:10.2527/jas.53770. 
González-Alvarado, J. M., E. Jiménez-Moreno, D. GonzálezSánchez, R. Lázaro, and G. G. Mateos. 2010. Effect of inclusion of oat hulls and sugar beet pulp in the diet on productive performance and digestive traits of broilers from 1 to 42 days of age. Anim. Feed Sci. Technol. 162:37-46. doi:10.1016/j. anifeedsci.2010.08.010.

González-Alvarado, J. M., E. Jiménez-Moreno, D. G. Valencia, R. Lázaro, and G. G. Mateos. 2008. Effects of fiber source and heat processing of the cereal on the development and $\mathrm{pH}$ of the gastrointestinal tract of broilers fed diets based on corn or rice. Poult. Sci. 87:1779-1795. doi:10.3382/ps.2008-00070.

Goodband, B., M. Tokach, S. Dritz, J. DeRouchey, and J. Woodworth. 2014. Practical starter pig amino acid requirements in relation to immunity, gut health and growth performance. J. Anim. Sci. Biotechnol. 5:12-23. doi:10.1186/2049-1891-5-12.

Graham, H., and P. Aman. 1991. Nutritional aspects of dietary fibres. Anim. Feed Sci. Technol. 32:143-158. doi:10.1016/03778401(91)90018-N.

Guzmán, P., B. Saldaña, H. A. Mandalawi, A. Pérez-Bonilla, R. Lázaro, and G. G. Mateos. 2015. Productive performance of brown-egg laying pullets from hatching to 5 weeks of age as affected by fiber inclusion, feed form, and energy concentration of the diet. Poult. Sci. 94:249-261. doi:10.3382/ps/peu072.

Hedemann, M. S., M. Eskildsen, H. N. Laerke, C. Pedersen, J. E. Lindberg, P. Laurinen, and K. E. Bach Knudsen. 2006. Intestinal morphology and enzymatic activity in newly weaned pigs fed contrasting fiber concentrations and fiber properties. J. Anim. Sci. 84:1375-1386.

Hermes, R. G., F. Molist, M. Ywazaki, M. Nofrarías, A. Gomez de Segura, J. Gasa, and J. F. Pérez. 2009. Effect of dietary level of protein and fiber on the productive performance and health status of piglets. J. Anim. Sci. 87:3569-3577. doi:10.2527/ jas.2008-1241.

Hogberg, A., and J. E. Lindberg. 2006. The effect of level and type of cereal non-starch polysaccharides on the performance, nutrient utilization and gut environment of pigs around weaning. Anim. Feed Sci. Technol. 127:200-219. doi:10.1016/j. anifeedsci.2005.09.004.

Jaworski, N. W., H. N. Laerke, K. E. Bach Knudsen, and H. H. Stein. 2015. Carbohydrate composition and in vitro digestibility of dry matter and nonstarch polysaccharides in corn, sorghum, and wheat and coproducts from these grains. J. Anim. Sci. 93:1103-1113. doi:10.2527/jas.2014-8147.

Jiménez-Moreno, E., M. Frikha, A. de Coca-Sinova, J. García, and G. G. Mateos. 2013. Oat hulls and sugar beet pulp in diets for broilers 1. Effects on growth performance and nutrient digestibility. Anim. Feed Sci. Technol. 182:33-43. doi:10.1016/j. anifeedsci.2013.03.011.

Jiménez-Moreno, E., J. M. González-Alvarado, A. de CocaSinova, R. Lázaro, and G. G. Mateos. 2009. Effects of source of fibre on the development and $\mathrm{pH}$ of the gastrointestinal tract of broilers. Anim. Feed Sci. Technol. 154:93-101. doi:10.1016/j.anifeedsci.2009.06.020.

Jørgensen, H., A. Serena, M. S. Hedemann, and K. E. Bach Knudsen. 2007. The fermentative capacity of growing pigs and adult sows fed diets with contrasting type and level of dietary fibre. Livest. Sci. 109:111-114. doi:10.1016/j.livsci.2007.01.102.

Konstantinov, S. R., W. Y. Zhu, A. B. Williams, S. Tamminga, W. M. de Vos, and A. D. L. Akkermans. 2003. Effect of fermentable carbohydrates on piglet faecal bacterial communities as revealed by denaturing gradient gel electrophoresis analysis of 16S ribosomal DNA. FEMS Microbiol. Ecol. 43:225-235. doi:10.1111/j.1574-6941.2003.tb01062.x.
Le Floc'h, N., L. Le Bellego, J. J. Matte, D. Melchior, and B. Sève. 2009. The effect of sanitary status degradation and dietary tryptophan content on growth rate and tryptophan metabolism in weaning pigs. J. Anim. Sci. 87:1686-1694. doi: $10.2527 /$ jas.2008-1348.

Lindberg, J. E. 2014. Fiber effects in nutrition and gut health in pigs. J. Anim. Sci. Biotechnol. 5:15-22. doi:10.1186/2049-1891-5-15.

Lizardo, R., J. Peiniau, and A. Aumaitre. 1997. Inclusion of sugar-beet pulp and change of protein source in the diet of the weaned piglet and their effects on digestive performance and enzymatic activities. Anim. Feed Sci. Technol. 66:1-14. doi:10.1016/S0377-8401(96)01144-3.

Longland, A. C., J. Carruthers, and A. G. Low. 1994. The ability of piglets 4 to 8 weeks old to digest and perform on diets containing two contrasting sources of non-starch polysaccharide. Anim. Prod. 58:405-410. doi:10.1017/S0003356100007352.

Mateos, G. G., E. Jiménez-Moreno, M. P. Serrano, and R. P. Lázaro. 2012. Poultry response to high levels of dietary fiber sources varying in physical and chemical characteristics. J. Appl. Poult. Res. 21:156-174. doi:10.3382/japr.2011-00477.

Mateos, G. G., E. López, M. A. Latorre, B. Vicente, and R. P. Lázaro. 2007. The effect of inclusion of oat hulls in piglet diets based on raw or cooked rice and maize. Anim. Feed Sci. Technol. 135:100-112. doi:10.1016/j.anifeedsci.2006.07.006.

Mateos, G. G., F. Martin, M. A. Latorre, B. Vicente, and R. Lazaro. 2006. Inclusion of oat hulls in diets for young pigs based on cooked maize or cooked rice. Anim. Sci. 82:57-63. doi: $10.1079 /$ ASC20053.

Medel, P., S. Salado, J. C. de Blas, and G. G. Mateos. 1999. Processed cereals in diets for early-weaned piglets. Anim. Feed Sci. Technol. 82:145-156. doi:10.1016/S0377-8401(99)00111-X.

Molist, F., A. Gómez de Segura, J. Gasa, R. G. Hermes, E. G. Manzanilla, M. Anguita, and J. F. Pérez. 2009. Effects of the insoluble and soluble dietary fibre on the physicochemical properties of digesta and the microbial activity in early weaned piglets. Anim. Feed Sci. Technol. 149:346-353. doi:10.1016/j.anifeedsci.2008.06.015.

Molist, F., M. van Oostrum, J. F. Pérez, G. G. Mateos, C. M. Nyachoti, and P. J. van der Aar. 2014. Relevance of functional properties of dietary fibre in diets for weanling pigs. Anim. Feed Sci. Technol. 189:1-10. doi:10.1016/j.anifeedsci.2013.12.013.

Molist, F., M. Ywazaki, A. Gómez de Segura, R. G. Hermes, J. Gasa, and J. F. Pérez. 2010. Administration of loperamide and addition of wheat bran to the diets of weaner pigs decrease the incidence of diarrhoea and enhance their gut maturation. Br. J. Nutr. 103:879-885. doi:10.1017/S0007114509992637.

Montagne, L., N. Le Floc'h, M. Arturo-Schaan, R. Foret, M. C. Urdaci, and M. Le Gall. 2012. Comparative effects of level of dietary fiber and sanitary conditions on the growth and health of weanling pigs. J. Anim. Sci. 87:3569-3577.

Montagne, L., J. R. Pluske, and D. J. Hampson. 2003. A review of interactions between dietary fibre and the intestinal mucosa, and their consequences on digestive health in young non-ruminant animals. Anim. Feed Sci. Technol. 108:95-117. doi:10.1016/S0377-8401(03)00163-9.

Pascoal, L. A. F., M. C. Thomaz, P. H. Watanabe, U. S. Ruiz, J. M. B. Ezequiel, A. B. Amorim, E. Daniel, and G. C. I. Masson. 2012. Fiber sources in diets for newly weaned piglets. R. Bras. Zootec. 41:636-642. doi:10.1590/S151635982012000300024.

Pluske, J. R., Z. Durmic, D. W. Pethick, B. P. Mullan, and D. J. Hampson. 1998. Confirmation of the role of rapidly fermentable carbohydrates in the expression of swine dysentery in pigs after experimental infection. J. Nutr. 128:1737-1744. 
Ravindran, V., and E. T. Kornegay. 1993. Acidification of weaner pig diets: A review. J. Sci. Food Agric. 62:313-322. doi:10.1002/jsfa.2740620402.

Romero, C., N. Nicodemus, J. D. Rodríguez, A. I. García, and C. de Blas. 2011. Effect of type of grinding of barley and dehydrated alfalfa on performance, digestion, and crude mucin ileal concentration in growing rabbits. J. Anim. Sci. 89:24722484. doi:10.2527/jas.2010-3226.

Schiavon, S., F. Tagliapietra, L. Bailoni, and A. Bortolozzo. 2004. Effects of sugar beet pulp on growth and health status of weaned piglets. Ital. J. Anim. Sci. 3:337-351. doi:10.4081/ijas.2004.337.

Solà-Oriol, D., D. Torrallardona, and J. Gasa. 2010. Role of dietary fibre source and meal size on the ileal transit of digesta in growing pigs. Livest. Sci. 133:67-69. doi:10.1016/j.livsci.2010.06.027.

Thomson, L. W., R. Pieper, J. K. Marshall, and A. G. Van Kessel. 2012. Effect of wheat distillers dried grains with solubles or sugar beet pulp on prevalence of Salmonella enterica Typhimurium in weaned pigs. J. Anim. Sci. 90:13-15. doi:10.2527/jas.53739.
Van Soest, P. J., J. B. Robertson, and A. Lewis. 1991. Methods for dietary fiber, neutral detergent fiber, and non-starch polysaccharides in relation to animal nutrition. J. Dairy Sci. 74:3583-3597. doi:10.3168/jds.S0022-0302(91)78551-2.

Vicente, B., D. G. Valencia, M. P. Serrano, R. Lázaro, and G. G. Mateos. 2009. Effects of feeding rice and the degree of starch gelatinization of rice on nutrient digestibility and ileal morphology of young pigs. Br. J. Nutr. 101:1278-1281. doi:10.1017/S0007114508060789.

Wellock, I. J., P. D. Fortomaris, J. G. M. Houdijk, J. Wiseman, and I. Kyriazakis. 2008. The consequences of non-starch polysaccharide solubility and inclusion level on the health and performance of weaned pigs challenged with enterotoxigenic Escherichia coli. Br. J. Nutr. 99:520-530. doi:10.1017/S0007114507819167.

Zhang, W., D. Li, L. Liu, J. Zang, Q. Duan, W. Yang, and L. Zhang. 2013. The effects of dietary fiber level on nutrient digestibility in growing pigs. J. Anim. Sci. Biotechnol. 15:4-17. 